\title{
Application of STR Typing in Solving a Case of Paternity After Sexual Assault: Case study
}

\author{
Amany A. Mousa*
}

\begin{abstract}
:
In forensic field, paternity testing is an important tool for approve or disapprove a biological relationship to a child, when a child paternity is in doubt, especially in sexual assault. Similarly, the maternity testing, but it is less common, except in some cases where the biological mother of a child is unclear as in case of surrogate mother. The technique of STR typing can be applied to both paternity and maternity testing.

Materials and Methods: DNA extracted from all blood samples of four suspects, mother, and the twin girls) followed by quantitation, amplification, and detection steps. Then analysis of the results was obtained. Results: The fourth suspect is the real biological father of the twin girls.

Keywords: Short Tandem Repeats (STRs), Deoxyribonucleic Acid (DNA), Maternity, Paternity; Polymerase Chain Reaction (PCR).
\end{abstract}

\section{Introduction:}

Nowadays, the analysis of genetic markers is a very important and validated tool for the identification of individuals, and for paternity testing. To do so, highly variable regions of the human genome are analyzed, making it possible to obtain the genetic profile of an individual, and to distinguish between different individuals. The methodology used is basically the same all over the world, consisting of the analysis of 13 to 15 markers. To assign biological paternity the child must have inherited the characteristics from the alleged father in each of the genetic markers analyzed. This analysis achieves a certainty higher than with any other test, which is expressed as the probability of paternity. If the characteristics of two or more genetic markers from the alleged father are absent in the child, biological paternity is excluded as Lagos and his colleges reported in their study ${ }^{[1]}$. New DNA typing technology has opened new possibilities to perform human identity testing. Personal human identification is imperative in a number of situations including the determination of perpetrators of violent crimes such as murder and sexual assault, and also the identification of remains of missing persons or victims of mass disaster ${ }^{[2,3,4]}$. Forensic DNA typing has

* Lecturer in Faculty of Biotechnology, October University for Modern Sciences and Arts, MD Clinical Pathology \& Chemical Pathology.

The National Review of Criminal Sciences, Volume 63, No. 3, November 2020. 
an important impact on the society by providing reliable evidence both for convicting the offenders and for exonerating the innocent suspects. Another field of application of DNA Typing is paternity testing and testing for relatedness on the maternal or the paternal lineage using autosomal, mitochondrial or Y-chromosomal DNA markers ${ }^{[5,6,7]}$. In different ways, DNA typing techniques have increased the ability to solve problems of family relationships and forensic cases that might have otherwise been left unsolved. To identify individuals, forensic scientists scan 13 DNA regions, or loci, that vary from person to person and use the data to create a complete DNA profile of that individual (sometimes called a DNA fingerprint). So, that's to say, there is an extremely small percent that another person has the same DNA profile for a particular set of 13 DNA regions ${ }^{[8]}$.

\section{Aim of the Work:}

The Study shows the power of using STR typing as a rich source of highly polymorphic markers (15 STR loci) in solving paternity cases.

\section{The Story of the Case:}

At one wintery night 2016 in a rural area in upper Egypt, four adult males raped a virgin girl and left her in a state of severe exhaustion amidst agriculture. People found her and transferred her to the nearest hospital. After the medical care necessary help, she left the hospital for fear of scandal because she is poor living in a rural town, she informed the police only after the birth of two identical female twins. The police began the investigation of the crime, asking her about the suspects. She described the incident telling the investigator about four males who raped her, and gave their descriptions. The police arrested three of the defendants, and the paternity testing was carried out to all DNA profiles and the results compared with the mother and the two girls, but none of them was the biological legal father for the female twins. The fourth suspect escaped for more than two years by traveling to another country. One day, the fourth suspect returned to the village, arrested by the police and the paternity testing was carried out comparing his result with the female twins and the mother.

\section{DNA Extraction:}

DNA was extracted from the blood samples of the 4 defendants, the mother and the two girls (identical twin) by using QIAamp ${ }^{\circledR}$ DNA Mini Kit 
(QIAGEN,USA), following the manufacturer protocol ${ }^{[9]}$. During extraction, appropriate controls and decontamination precautions were assured to monitor and prevent any possible contamination.

\section{DNA Quantitation:}

All DNA samples were quantified by using the Quantifiler1 Human DNA Quantification Kit (Applied Biosystems) with the ABI PRISM1 7000 Sequence Detection System (Applied Biosystems), as the manufacturer's instructions ${ }^{[10]}$.

\section{STR Amplification and Typing:}

Using the AmpFlSTR ${ }^{\circledR}$ Identifiler ${ }^{\circledR}$ plus PCR Amplification Kit (Applied Biosystems). PCR was carried out in a 25 ul volume using 1-5 ng template DNA, 2.5 ul of 10 reaction buffer, 5.5 ul of primer set and 4 units of AmpliTaq Gold DNA polymerase following the procedure recommended by the manufacturer ${ }^{[11]}$. A negative control with no DNA template was used. PCR was performed by using GeneAmp-9700 thermal cycler (Applied Biosystems) with the following amplification conditions: an initial denaturation at $95^{\circ} \mathrm{C}$ for $11 \mathrm{~min} ; 28$ cycles of $94^{\circ} \mathrm{C}$ for $1 \mathrm{~min}, 59^{\circ} \mathrm{C}$ for 1 min and $72^{\circ} \mathrm{C}$ for $1 \mathrm{~min}$, and a final extension of $60^{\circ} \mathrm{C}$ for $60 \mathrm{~min}$ to enable full addition to the PCR products.

\section{Detection and Analysis:}

The amplified products were analyzed using the ABI PRISM 310 Genetic Analyzer (Applied Biosystems). One microliter of each PCR reaction product was added to $24 \mathrm{ul}$ of deionized formamide (Sigma, St Louis, MO, USA) and $0.5 \mathrm{ul}$ of Gene Scan 500 LIZ size standard (Applied Biosystems). PCR products were denatured at $95{ }^{\circ} \mathrm{C}$ for $3 \mathrm{~min}$ and chilled for $3 \mathrm{~min}$. Electrophoresis was performed using the Performance Optimized Polymer 4 (Applied Biosystems) with a $47 \mathrm{~cm} / 50 \mathrm{ml}$ capillary at $15 \mathrm{kV}$ for $30 \mathrm{~min}$ at $60{ }^{\circ} \mathrm{C}$. Data were analyzed using Gene Scan and Geno-Typer Analysis software (Applied Biosystems) to assess the quality of PCR amplification and to assign the specific alleles to each product analyzed.

\section{Results:}

The results presented in the table below, showed that, the fourth suspect is the real legal father for the female twin, and the mother is the real mother for the two girls. 
Table: STR Profiles of the 4 Defendants, Twin Girls, and Mother.

\begin{tabular}{|c|c|c|c|c|c|c|}
\hline Loci & Mother & Identical twin & Susp.1 & Susp.2 & Susp.3 & Susp.4 \\
\hline D8S1179 & 13,16 & 13,14 & $\mathbf{1 2 , 1 4}$ & $\mathbf{1 3 , 1 4}$ & $\mathbf{1 1 , 1 3}$ & $\mathbf{1 4 , 1 5}$ \\
\hline D21S11 & $\mathbf{2 8 , 3 1}$ & $\mathbf{2 8 , 3 2 . 2}$ & $\mathbf{3 1 . 2 , 3 1 . 2}$ & $\mathbf{2 6 , 2 8}$ & $\mathbf{2 8 , 3 0}$ & $\mathbf{3 0 , 3 2 . 2}$ \\
\hline D7S820 & $\mathbf{1 1 , 1 2}$ & $\mathbf{9 , 1 1}$ & $\mathbf{1 0 , 1 2}$ & $\mathbf{9 , 1 0}$ & $\mathbf{1 0 , 1 2}$ & $\mathbf{9 , 1 1}$ \\
\hline CSF1PO & $\mathbf{1 2 , 1 3}$ & $\mathbf{1 0 , 1 3}$ & $\mathbf{8 , 1 2}$ & $\mathbf{1 0 , 1 1}$ & $\mathbf{1 1 , 1 2}$ & $\mathbf{1 0 , 1 2}$ \\
\hline D3S1358 & $\mathbf{1 4 , 1 7}$ & $\mathbf{1 6 , 1 7}$ & $\mathbf{1 5 , 1 6}$ & $\mathbf{1 5 , 1 5}$ & $\mathbf{1 7 , 1 8}$ & $\mathbf{1 5 , 1 6}$ \\
\hline THO1 & $\mathbf{7 , 9}$ & $\mathbf{9 , 9}$ & $\mathbf{6 , 9 . 3}$ & $\mathbf{7 , 8}$ & $\mathbf{9 , 9 . 3}$ & $\mathbf{9 , 9}$ \\
\hline D13S317 & $\mathbf{1 2 , 1 2}$ & $\mathbf{1 2 , 1 2}$ & $\mathbf{8 , 1 2}$ & $\mathbf{1 1 , 1 3}$ & $\mathbf{1 0 , 1 1}$ & $\mathbf{1 0 , 1 2}$ \\
\hline D16S539 & $\mathbf{1 1 , 1 2}$ & $\mathbf{1 1 , 1 2}$ & $\mathbf{9 , 1 0}$ & $\mathbf{1 1 , 1 2}$ & $\mathbf{9 , 1 0}$ & $\mathbf{9 , 1 1}$ \\
\hline D2S1338 & $\mathbf{2 0 , 2 3}$ & $\mathbf{1 6 , 2 0}$ & $\mathbf{1 7 , 1 7}$ & $\mathbf{1 8 , 1 9}$ & $\mathbf{1 8 , 1 8}$ & $\mathbf{1 6 , 2 4}$ \\
\hline D19S433 & $\mathbf{1 3 , 1 4}$ & $\mathbf{1 3 , 1 4}$ & $\mathbf{1 2 , 1 4}$ & $\mathbf{1 1 , 1 5}$ & $\mathbf{1 3 , 1 4}$ & $\mathbf{1 2 , 1 3}$ \\
\hline VWA & $\mathbf{1 6 , 1 6}$ & $\mathbf{1 6 , 1 8}$ & $\mathbf{1 7 , 1 8}$ & $\mathbf{1 5 , 1 6}$ & $\mathbf{1 5 , 1 6}$ & $\mathbf{1 6 , 1 8}$ \\
\hline TPOX & $\mathbf{8 , 9}$ & $\mathbf{8 , 8}$ & $\mathbf{9 , 1 1}$ & $\mathbf{1 1 , 1 1}$ & $\mathbf{8 , 1 1}$ & $\mathbf{8 , 8}$ \\
\hline D18S51 & $\mathbf{1 5 , 1 7}$ & $\mathbf{1 2 , 1 7}$ & $\mathbf{1 3 , 1 5}$ & $\mathbf{1 3 , 1 6}$ & $\mathbf{1 3 , 1 4}$ & $\mathbf{1 1 , 1 2}$ \\
\hline Amel. & $\mathbf{X , X}$ & $\mathbf{X}, \mathbf{X}$ & $\mathbf{X , Y}$ & $\mathbf{X}, \mathbf{Y}$ & $\mathbf{X}, \mathbf{Y}$ & $\mathbf{X , Y}$ \\
\hline D5S818 & $\mathbf{1 2 , 1 2}$ & $\mathbf{1 2 , 1 2}$ & $\mathbf{1 2 , 1 3}$ & $\mathbf{9 , 1 3}$ & $\mathbf{9 , 1 1}$ & $\mathbf{9 , 1 2}$ \\
\hline FGA & $\mathbf{1 9 , 2 2}$ & $\mathbf{1 9 , 2 4}$ & $\mathbf{2 0 , 2 3}$ & $\mathbf{1 9 , 2 3}$ & $\mathbf{2 2 , 2 5}$ & $\mathbf{2 0 , 2 4}$ \\
\hline
\end{tabular}

\section{Discussion:}

A paternity test is a genetic test that aim to establish findings concerning family ties: usually a mother and child with a possible father. Other first degree relations may also be established, such as siblings. In present casework the female twin are the daughters of the fourth suspect because half of their alleles matched with half alleles of the fourth suspect, but not with any of the other three suspects and the rest of their alleles matched with their mother (victim of the rape crime). If all the markers tested in a person are found in his alleged biological parent too, the conclusion is that there is a very high degree of probability that the mother and father are the parents. If the results of the test show such a match, the result is considered in courts as "nearly certain" evidence of family links between the subjects. Short tandem repeat analysis can handle forensic samples that are of low quantity and of poor quality. In addition, Short tandem repeats can be multiplexed ${ }^{[12]}$ and their detection could be easily automated to solve such cases ${ }^{[13,14]}$. El-Alfy and Abd El-Hafez in 2012, revealed in their study that, STR typing is a reliable and robust genetic tool which has an important central role in the society to solve problems of family relationships and forensic caseworks ${ }^{[15]}$. The present study has shown that a pattern of 15 polymorphic STR loci offers a discriminating power sufficient to exclude or include alleged father in disputed paternity cases. This is consistent with 
many reports which described the usefulness and discrimination power of STR markers $[16,17,18,19]$.

DNA typing has an advantage over traditional protein analysis and it is more informative and can be analyzed in minute and/or degraded material as DNA is physically much more resistant to degradation than protein. DNA analysis provides the best avenue for unequivocal exclusion of the innocent suspects. Due to all these impressive applications, DNA test has become the darling of the criminal and civil justice system globally ${ }^{[20]}$. In the present case, after the analysis of all DNA profiles of the three defendants who were involved in the rape crime and fled, DNA typing proved that the biological father was the fourth suspect because the two girls inherited half of their alleles from him and the other half from their mother and nothing from the other defendants. DNA typing compared strands of genetic material of the two girls and the fourth suspect (alleged father) i.e comparing strands from various locations of the genetic material allows accuracy ratings of 99.9 percent ${ }^{[21]}$. On conclusion, STR typing is a reliable and robust genetic tool which has an important central role in the society to solve problems of family relationships and forensic caseworks.

\section{Acknoledgement:}

It is a delightful duty to thank all those people who made this publication possible. I sincerely acknowledge the guidance assistance offered to me by my colleagues in medical labs of Egyptian Forensic Medicolegal Authority [EFMA], for their immense support and encouragement to accomplish . 


\section{References}

1- Lagos, M., Poggi, H., Mellado, C. (2011), Basic Concepts About Paternity Testing, Rev Med Chil.,139 (4): 542-7.

2- Gill, P., Ivanov, P.L., Kimpton, C., Piercy, R., Benson, N., Tully, G., Evett, I., Hagelberg, E., Sullivan, K. (1994), Nat. Genet., 6: 130-135.

3- Clayton, T.M., Whitaker, J.P., Maguire, C.N. (1995), Forensic Sci. Int., 76: 7-15.

4- Okamoto, O., Yamamoto, Y., Inagaki, S., Yoshitome, K., Ishikawa, T., Imabayashi, K., Miyaishi, S., Ishizu, H. (2003), Acta Med. Okayama, 57: 59-71.

5- Thomson, J.A., Pilotti, V., Stevens, P., Ayres, K.L., Debenham, P.G. (1999), Forensic Sci. Int., 100:1-16.

6- Torroni, A., Achilli, A., Macaulay, V., Richards, M., Bandelt, H.J. (2006), Trends Genet, 22: 339-345.

7- Rodig, H., Roewer, L., Gross, A., Richter, T., Knijff, P., Kayser, M., Brabetz, W. (2008), Forensic Sci. Int., 174: 182-188.

8- Subramanyam, G., Damerla, H., Reddy, G. (2012), Paternity Testing Through Multiplex PCR Based STR Genotyping of Genomic DNA, J. Bio. Innov., 12: 41-47.

9- QIAamp DNA Mini Kit and QIAamp DNA Blood Mini Kit Handbook, Qiagen (2001).

10- Applied Biosystems, Foster City, CA (USA). Quantifiler TM Kits: Quantifiler Human DNA Quantification Kit and Quantifiler TM Y Human Male DNA Quantification Kit. User's Manual. Rev. B., November (2003).

11- Amp FlSTR Identifier PCR Amplification kit, User's Manual, PE Biosystems (2001).

12- M.C. Edwards, R.A. Gibbs (1994), PCR Methods Appl., 3: 565-575.

13- Oldroyd, N.J., Urquhart, A.J., Kimpton, C.P., Millican, E.S., Atson, S.K., Downes, T., Gill, P. (1995), Electrophoresis, 16: 334-337.

14- Hahner, S., Schneider, A., Ingendoh, A., Mosner, J. (2000), Nucleic Acids, e82: iviii.

15- El-Alfy, S.H., Abd El-Hafez, A.F. (2012), Paternity Testing and Forensic DNA Typing by Multiplex STR Analysis Using ABI PRISM 310 Genetic Analyzer, Journal of Genetic Engineering and Biotechnology, 10: 101-112.

16- Chen, D.P., Tseng, C.P., Tsai, S.H., Wang, M.C., S.C. Lu, S.C., Wu, T.L., Chang, P.Y., Sun, C.F. (2009), Clin. Chim. Acta, 408: 29- 33.

17- Csete, K., Beer, Z., Varga, T. (2005), Forensic Sci. Int., 147S: S57-S60.

18- Geada, H., Brito, R.M., Ribeiro, T., Espinheira. R. (2000), Forensic Sci. Int., 108: 31-37. 
19- Thomson, J.A., Pilotti, V., Stevens, P., Ayres, K.L., Debenham, P.G. (1999), Forensic Sci. Int., 100: 1-16.

20- Amarnath, M., Sukumaran, S. (2016), Role of DNA Finger Printing in Disputed Paternity. Case Report, MED Phoenix, An Official Journal of NMC, Birgunj, Nepal, Volume (1), Issue(1).

21- Lygo, J.E., Johnson, P.E., Holdaway, D.J., Woodroffe, S., Whitaker, J.P., et al. (1994), The validation of Short Tandem Repeat (STR) Loci for Use in Forensic Case Work, Int. J. Legal Med., 107: 77-89. 


\section{تطبيق تقنية تنميط التكرارات المترادفة القصيرة للحمض النووى الوراثى \\ فى حالة إببات الأبوة فى قضايا الاغتصاب: دراسة حالة \\ أمهانى هموسى}

يُعد اختبار إثبات الأبوة فى مجال الطب الشرعى من التقنيات المهمة فى إثبات أو عدم إثبات

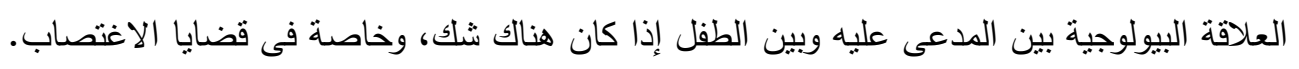

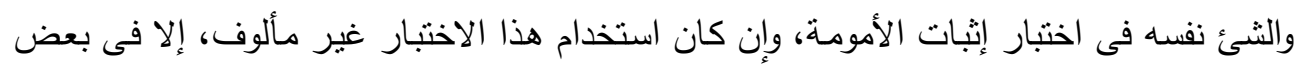

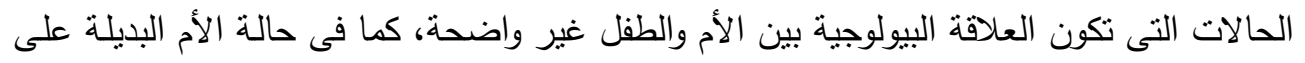

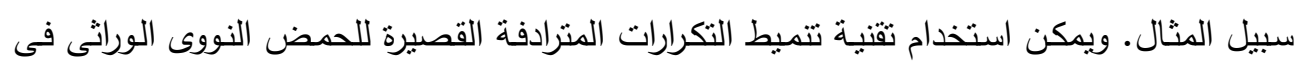
كل من حالتى إثبات الأبوة وإثبات الأمومة على حد سواء. 